\title{
PENGARUH SUHU AIR PENCUCIAN AMBING DAN TEAT DIPPING TERHADAP JUMLAH PRODUKSI, KUALITAS DAN JUMLAH SEL SOMATIK SUSU PADA SAPI PERANAKAN FRIESIAN HOLSTEIN
}

\section{THE EFFECT OF UDDER WASH WATER TEMPERATURE AND TEAT DIPPING ON THE NUMBER OF PRODUCT, QUALITY AND SOMATIC CELL IN MILK OF FRIESIAN HOLSTEIN GRADE COW}

\author{
Happy Aprillia Mahardika*, Pratiwi Trisunuwati, dan Puguh Surjowardojo \\ Fakultas Peternakan, Universitas Brawijaya, Malang, 65145
}

Submitted: 21 December 2015, Accepted: 10 February 2016

\section{INTISARI}

Penelitian ini bertujuan untuk mengetahui pengaruh pencelupan puting dan suhu pencucian ambing terhadap kuantitas, kualitas dan jumlah sel somatik susu sapi Peranakan Friesian Holstein (PFH) di koperasi susu SAE Pujon, Malang. Sejumlah 16 sapi PFH laktasi digunakan dalam penelitian yang dibagi dalam 4 perlakuan: P0 (suhu $19-22^{\circ} \mathrm{C}$, tanpa dipping), P1 (suhu $19-22^{\circ} \mathrm{C}$ dengan dipping setelah pemerahan), P2 (suhu $37^{\circ} \mathrm{C}$ dengan dipping sesudah pemerahan), dan $\mathrm{P} 3$ (suhu $37^{\circ} \mathrm{C}$ dengan dipping sebelum dan sesudah pemerahan). Kualitas suhu yang meliputi protein, lemak, padatan tanpa lemak (solid non fat), padatan, densitas dan kadar laktosa dianalisis menggunakan alat "lactoscan", uji mikroorganisme dengan uji reduktase. Pengujian jumlah sel somatic dengan metode pembibitan (breed) dan jumlah produksi susu dihitung pada pagi dan sore hari. Hasil penelitian menunjukkan bahwa dipping dapat meningkatkan nilai reduktase sampai dengan 7,3 jam dan menurunkan angka somatic sel. Suhu pencucian ambing pada $37^{\circ} \mathrm{C}$ mempengaruhi produksi susu tetapi tidak berpengaruh pada kualitas susu.

(Kata kunci: Kualitas susu, Sapi perah, Teat dipping)

\section{ABSTRACT}

This study aimed to investigate the effect of teat dipping on the number of microorganisms based on reductase test and somatic cell, as well as determine the effect udder wash water temperature (temperature of $19-22{ }^{\circ} \mathrm{C}$ and $37^{\circ} \mathrm{C}$ ) on the quality of milk components and quantity of milk production in cows PFH located in KOP SAE Pujon. Sixteen PFH lactation cows were used to test the milk quality with 4 treatments: $P O$ (temperature $19-22^{\circ} \mathrm{C}$, without teat dipping), $P 1$ (temperature $19-22^{\circ} \mathrm{C}$ with teat dipping after milking), $P 2$ (temperature $37^{\circ} \mathrm{C}$ with teat dipping after milking) and $P 3$ (temperature $37^{\circ} \mathrm{C}$ with teat dipping before and after milking). The quality of the milk consists of protein, fat, SNF, solid, density and lactose were analyzed by Lactoscan, microbial test using reductase test, a test of counting the number of somatic cells by the method of breeds, and the amount of production was measured in the morning and afternoon. The results indicated the teat dipping able to increase the time up to 7.3 hours reductase and decrease the number of somatic cell. Water temperature $37^{\circ} \mathrm{C}$ affected the milk production, but no effect to the milk quality.

(Key words: Dairy cows, Milk quality, Teat dipping)

\section{Pendahuluan}

Rendahnya produksi susu sapi perah di Indonesia dapat disebabkan beberapa faktor, yaitu genetik, pakan dan lingkungan. Manajemen pemerahan merupakan salah satu bagian dari faktor lingkungan. Manajemen pemerahan dibagi menjadi tiga tahap yaitu tahap persiapan, tahap pelaksanaan pemerahan dan tahap pengakhiran (Surjowardojo, 2011). Tahap persiapan pemerahan meliputi kegiatan menyediakan sarana untuk melakukan pemerahan, membersihkan kandang, memandikan sapi, mencuci ambing dan membuang 3-4 pancaran pertama (Widaningrum et al., 2006). Ambing sebelum pemerahan perlu dilakukan pencucian. Pencucian ambing berfungsi agar ambing dalam keadaan bersih dan merangsang keluarnya

\footnotetext{
${ }^{*}$ Korespondensi (corresponding author):

Telp. +62 341553513

E-mail: happypinky_girl@yahoo.co.id
} 
air susu, sehingga dalam pencucian ini perlu diperhatikan agar peternak tidak banyak kehilangan produksi susu. Kentjonowaty et al. (2014) menyatakan bahwa pencucian ambing erat hubungannya dengan perangsangan dan aktifitas hormon oxytocin. Hormon oxytocin merupakan hormon yang khusus untuk merangsang keluarnya air susu dari alveoli. Kerja oxytocin berlangsung 6-8 menit sehingga pemerahan perlu dilakukan secara cepat dan optimal agar produksi susu dapat diperoleh sebanyakbanyaknya, pemerahan susu yang tidak optimal menyebabkan penurunan kualitas komponen susu karena terdapat residual milk terutama pada kadar lemak yang disebabkan oleh adanya sel somatik dalam jumlah banyak sehingga kadar lemak turun. Sel somatik dalam susu merupakan sekresi epitel dan leokosit dalam susu.

Pencucian ambing menggunakan air bersuhu $37^{\circ} \mathrm{C}$ berguna untuk menghindari pencemaran bakteri dan juga merangsang keluarnya susu dari kelenjar-kelenjar susu dengan optimal, karena suhu $37^{\circ} \mathrm{C}$ merupakan suhu normal tubuh sapi dan ternak merasa nyaman karena hormon oxytocin bekerja dengan efektif dan menghambat keluarnya hormon adrenalin yang mengakibatkan terhentinya hormon oxytocin.

Tahap yang terakhir dalam kegiatan pemerahan adalah mencuci ambing dan melakukan teat dipping (Surjowardojo et al., 2008). Hal ini bertujuan agar tidak ada bakteri yang masuk dalam lubang puting (Wibowo, 2005). Keadaan di lapang jarang peternak yang melakukan teat dipping di akhir pemerahan, hal ini menyebabkan kualitas susu rendah. Tujuan penelitian ini untuk mengtahui perlakuan teat dipping dan mencuci ambing dengan suhu $37^{\circ} \mathrm{C}$ terhadap kualitas mikro dan komponen susu serta jumlah produksi susu pada sapi PFH milik KOP SAE Pujon.

\section{Materi dan Metode}

\section{Lokasi dan waktu penelitian}

Penelitian berlangsung di Kandang Unit Ternak Milik KOP SAE Pujon. KOP SAE Pujon ditentukan sebagai lokasi penelitian karena merupakan salah satu sentra persusuan di jawa timur dengan produksi susu 20.371.512,5 liter per hari. Penelitian dilakukan 1 bulan yaitu dari 15 November 14 Desember 2015.

\section{Materi}

Susu yang digunakan adalah susu yang berasal dari sapi yang dipelihara di kandang milik KOP SAE Pujon dengan pemeliharaan yang sama sebanyak 16 ekor. Alat dan bahan yang digunakan untuk uji mastitis: paddle dan reagen CMT, uji reduktase: tabung reaksi, waterbath dan methylene blue $0,25 \%$, uji sel somatik: mikroskop, alkohol 96\%, methylene blue, objeck glass, minyak emersi, uji kualitas komponen susu: Lactoscan Milk Analyzer tipe MCC buatan Belgia.

\section{Metode}

Metode penelitian yang digunakan adalah melakukan percobaan dengan 4 perlakuan dan 4 ulangan, seperti tersaji pada Tabel 1.

Variabel yang diukur terdiri dari variabel terikat dan variabel bebas. Variabel terikat yaitu jumlah produksi susu, kualitas susu (lemak, protein, BJ, laktosa, SNF dan Solid), jumlah sel somatik susu dan jumlah bakteri. Variabel bebas: suhu air pencucian ambing $\left(19-22^{\circ} \mathrm{C}\right.$ dan $\left.37^{\circ} \mathrm{C}\right)$ dan teat dipping.

\section{Analisa data}

Penelitan di desain dengan Rancangan Acak Kelompok (RAK) dan dianalisis menggunakan Ancova.

\section{Hasil dan Pembahasan}

\section{Pengaruh teat dipping terhadap kualitas mikrobiologis susu}

Uji reduktase. Kualitas hyginie susu dapat ditentukan berdasarkan uji reduktase dengan indikator perubahan warna susu dari biru akibat pemberian methylene blue menjadi putih kembali. Hasil uji reduktase ditunjukkan pada Tabel 2 .

Tabel 2 menunjukkan bahwa hasil terbaik diperoleh pada P3 yaitu melakukan pencelupan puting sebelum pemerahan dan setelah pemerahan dengan hasil uji reduktase 7,3 jam, kemudian $\mathrm{P} 2$ dan $\mathrm{P} 1$ yaitu melakukan pencelupan setelah pemerahan. P3, P2 dan P1 dikategorikan menjadi grade 2 dengan kata lain kualitas susu cukup baik dengan perkiraan jumlah bakteri 1.000.000 hingga 4.000.000 sel per ml. Pada perlakukan kontrol (P0) susu dikategorikan menjadi grade 3 dengan kata lain kualitas susu kurang baik dengan perkiraan jumlah bakteri 4.000.000 hingga 20.000.000 sel per $\mathrm{ml}$, penilaian grade susu 
Tabel 1. Jenis perlakuan teat dipping dan pencucian ambing (treatments of teat dipping and under washing temperature)

\begin{tabular}{|c|c|c|c|c|c|}
\hline \multirow{2}{*}{$\begin{array}{l}\text { Perlakuan } \\
\text { (treatment) }\end{array}$} & \multirow{2}{*}{$\begin{array}{c}\text { Suhu }\left({ }^{\circ} \mathrm{C}\right) \\
\left(\text { temperature }\left({ }^{\circ} \mathrm{C}\right)\right)\end{array}$} & \multirow{2}{*}{$\begin{array}{l}\text { Lama } \\
\text { pencucian } \\
\text { (washing } \\
\text { time) }\end{array}$} & \multicolumn{2}{|c|}{$\begin{array}{c}\text { Teat dipping dengan konsentrasi } \\
\text { iodine } 2 \% \text { (teat dipping with } 2 \% \text { iodine } \\
\text { concentrate) }\end{array}$} & \multirow{2}{*}{$\begin{array}{c}\text { Lama teat } \\
\text { dipping } \\
\text { (teat } \\
\text { dipping } \\
\text { time) }\end{array}$} \\
\hline & & & $\begin{array}{c}\text { Sebelum } \\
\text { pemerahan } \\
\text { (before milking) }\end{array}$ & $\begin{array}{c}\text { Setelah } \\
\text { pemerahan (after } \\
\text { milking) }\end{array}$ & \\
\hline $\mathrm{PO}$ & $19-22$ & 60 detik & - & - & 5 detik \\
\hline P1 & $19-22$ & 60 detik & & $\sqrt{ }$ & 5 detik \\
\hline P2 & 37 & 60 detik & & $\sqrt{ }$ & 5 detik \\
\hline P3 & 37 & 60 detik & $\sqrt{ }$ & $\sqrt{ }$ & 5 detik \\
\hline
\end{tabular}

$\mathrm{P} 0$ : suhu $19-22^{\circ} \mathrm{C}$, tanpa dipping (temperature $19-22^{\circ} \mathrm{C}$, without teat dipping).

$\mathrm{P} 1$ : suhu $19-22^{\circ} \mathrm{C}$ dengan dipping setelah pemerahan (temperature $19-22^{\circ} \mathrm{C}$ with teat dipping after milking).

$\mathrm{P} 2$ : suhu $37^{\circ} \mathrm{C}$ dengan dipping sesudah pemerahan (temperature $37^{\circ} \mathrm{C}$ with teat dipping after milking).

P3: suhu $37^{\circ} \mathrm{C}$ dengan dipping sebelum dan sesudah pemerahan) (temperature $37^{\circ} \mathrm{C}$ with teat dipping before and after milking).

Tabel 2. Hasil uji reduktase (jam)

(the results of reductase test (hour))

\begin{tabular}{ccccc}
\hline \hline Waktu (time) & P0 & P1 & P2 & P3 \\
\hline Minggu 1 (1 week) & 5,6 & 4,2 & 5,7 & 4,7 \\
Minggu 2 (2 week) & 6,3 & 7 & 5,8 & 6,1 \\
Minggu 3 (3 week) & 5,8 & 6 & 7 & 7,3 \\
\hline
\end{tabular}

P0: suhu $19-22^{\circ} \mathrm{C}$, tanpa dipping (temperature $19-22^{\circ} \mathrm{C}$, without teat dipping).

$\mathrm{P} 1$ : suhu $19-22^{\circ} \mathrm{C}$ dengan dipping setelah pemerahan (temperature $19-22^{\circ} \mathrm{C}$ with teat dipping after milking).

$\mathrm{P} 2$ : suhu $37^{\circ} \mathrm{C}$ dengan dipping sesudah pemerahan (temperature $37^{\circ} \mathrm{C}$ with teat dipping after milking).

P3: suhu $37^{\circ} \mathrm{C}$ dengan dipping sebelum dan sesudah pemerahan) (temperature $37^{\circ} \mathrm{C}$ with teat dipping before and after milking).

sesuai dengan pernyataan Utami et al. (2014).

Perbedaan kualitas susu dengan uji reduktase disebabkan adanya perlakukan pencelupan puting, pencelupan puting sebelum pemerahan dapat mengurangi cemaran mikroorganisme saat pencucian ambing dengan air bersih, kontak ambing dengan bakteri yang berasal dari udara dan kandang, hal ini sesuai dengan penelitian Suriyasathaporn dan Chupia (2011) yang melakukan teat dipping sebelum pemerahan dapat mengurangi 3,5 kali jumlah mikroorganisme pada susu. Gilson (2015) menyatakan bahwa pencelupan puting sebelum pemerahan bertujuan untuk memastikan kebersihan ambing saat akan diperah yaitu dengan membunuh mikroorganisme yang melekat pada ambing.

Pemilihan bahan yang digunakan sebagai desinfektan adalah Streptocid dengan komposisi povidone iodine $2 \%$. Hal ini sesuai dengan pendapat Sugiri dan Anri (2014) bahwa desinfektan yang paling efektif adalah iodine dengan konsentrasi 0,5-2\%, desinfektan tersebut lebih efektif dibanding Benzalkonium chloroide dan iodine dengan konsentrasi $1 \%$. lodine mampu membunuh bakteri secara cepat jika dibanding dengan desinfektan jenis lain. Affandi et al. (2009) menyatakan bahwa povidone iodine merupakan bahan yang sering digunakan sebagai antiseptik, karena dapat mengurangi populasi bakteri hingga $85 \%$.

Sel somatik. Sel somatik susu merupakan indikasi adanya infeksi mastitis pada sapi $\mathrm{FH}$. Pemeriksaan mastitis dilakukan dengan California Mastitis Test (CMT) sehingga di dapat skor mastitis. Skor mastitis di lapang rerata adalah mastitis subklinis tingkat $1(+)$ yaitu dengan tanda timbulnya masa yang mengental. Sesuai dengan pendapat Surjowardojo (2012) bahwa apabila terjadi reaksi antara reagen CMT dan susu yang terinfeksi mastitis, maka pada paddle akan terlihat susu berubah warna menjadi ungu. Sampel susu dikumpulkan dan dibawa ke laboratorium dan dilakukan pengujian sel somatik dengan metode Breed. Hasil uji sel somatik disajikan pada Tabel 3.

Tabel 3 menunjukkan bahwa terdapat penurunan jumlah sel somatik pada P3, P2 dan P1, sedangkan kenaikan jumlah sel somatik terjadi pada PO. Sesuai pendapat Adriani (2010) bahwa semakin tinggi jumlah sel somatik susu maka semakin tinggi skor mastitis. Perbedaan jumlah sel somatik 
Tabel 3. Hasil pengujian sel somatic (the results of cell somatic test)

\begin{tabular}{lcc}
\hline \hline & Sebelum perlakuan (before treatment) & Sesudah perlakuan (after treatment) \\
\hline P0 & 84.875 & 85.675 \\
P1 & 73.8 & 56 \\
P2 & 59 & 50.9 \\
P3 & 66.675 & 41.2 \\
\hline
\end{tabular}

P0: suhu $19-22^{\circ} \mathrm{C}$, tanpa dipping (temperature $19-22^{\circ} \mathrm{C}$, without teat dipping).

$\mathrm{P} 1$ : suhu $19-22^{\circ} \mathrm{C}$ dengan dipping setelah pemerahan (temperature $19-22^{\circ} \mathrm{C}$ with teat dipping after milking).

$\mathrm{P} 2$ : suhu $37^{\circ} \mathrm{C}$ dengan dipping sesudah pemerahan (temperature $37^{\circ} \mathrm{C}$ with teat dipping after milking).

P3: suhu $37^{\circ} \mathrm{C}$ dengan dipping sebelum dan sesudah pemerahan) (temperature $37^{\circ} \mathrm{C}$ with teat dipping before and after milking).

disebabkan adanya perlakukan pencelupan puting pada $\mathrm{P} 3, \mathrm{P} 2$ dan $\mathrm{P} 1$, sedangkan $\mathrm{P} 0$ tidak melakukan pencelupan puting sehingga memungkinkan adanya peningkatan mastitis dari tingkat rendah ke tingkat yang lebih tinggi, hal ini terbukti adanya peningkatan jumlah sel somatik pada $\mathrm{P0}$ dari 84,875 menjadi 85,675 sel per $0,01 \mathrm{ml}$. Sesuai dengan penelitian Kurniawan et al. (2013) bahwa pencelupan puting dengan antiseptik mampu mengurangi skor mastitis dari rerata 0,6 menjadi 0,15 . Fungsi dari pencelupan puting adalah dapat menurunkan dan menekan jumlah sel somatik, sehingga kejadian mastitis dapat ditekan. Nickerson (2013) menyatakan bahwa mencelupkan puting di akhir pemerahan sangat efektif untuk mencegah infeksi baru yang disebabkan oleh mikroorganisme penyebab mastitis yang menular seperti Staphylococcus aureus dan Streptococcus agalactiae.

Jumlah sel somatik dalam susu sangat berkorelasi dengan kondisi ambing (Rajcevic et al. 2003). Sharma et al. (2011) menyatakan bahwa sel somatik adalah sel epitel yang disekresi oleh kelenjar ambing yang terinfeksi atau cidera, sel somatik terdiri dari $75 \%$ leokosit (neutrofil, makrofag, limfosit, eritrosit) dan $25 \%$ sel epitel. Sel darah putih berfungsi sebagai pertahanan untuk melawan infeksi dan membantu dalam perbaikan jaringan. Selama mastitis berlangsung jumlah sel somatik meningkat karena masuknya neotrofil ke dalam kelenjar ambing untuk melawan infeksi, sehingga jumlah sel somatik pada susu dapat dijadikan sebagai penentu kualitas susu (Ruegg dan Pantoja, 2013).

Pengaruh suhu air pencucian ambing terhadap kualitas komponen susu

Lemak. Pengujian kadar lemak susu pada susu sapi hasil penelitian menggunakan Lactoscan menghasilkan rerata di atas standar SNI yaitu 3\%. Lemak susu hasil penelitian tersaji pada Tabel 4 .

Tabel 4 menunjukkan bahwa penurunan kadar lemak sangat signifikan terjadi pada P0 yaitu sebesar 1,0075\%, sedangkan penurun kadar lemak signifikan pada $\mathrm{P} 3$ sebesar $0,18 \%$ dan $\mathrm{P} 1$ sebesar $0,27 \%$. Berbeda dengan P2 yang mengalami kenaikan kadar lemak secara signifikan yaitu $0,18 \%$. Penurunan dan kenaikan kadar lemak tidak dipengaruhi oleh suhu air pencucian ambing, melainkan disebabkan pakan terutama hijauan. Ace dan Wahyuningsih (2010) menyebutkan bahwa pakan secara signifikan dipengaruhi pakan. Mutamimah et al. (2013) menyatakan bahwa kadar lemak dipengaruhi oleh asam asetat yang berasal dari hijauan, sedangkan prekursor asam asetat berasal dari serat kasar yang difermentasi dalam rumen sehingga berubah menjadi VFA yang terdiri dari asetat, butirat dan propionat. Asam asetat yang kemudian masuk dalam sel-sel sekresi ambing dan menjadi lemak susu (Musnandar, 2011).

Selain itu lemak susu pada PO dipengaruhi adanya mastitis yang tertera pada Tabel 2. Sesuai dengan pendapat Surjowardojo (2012) pada saat mikroorganisme masuk sampai ke mukosa kelenjar, tubuh bereaksi menghasilkan leokosit sehingga menyebabkan perubahan susu yang ada di kelenjar ambing menjadi rusak, oleh karena adanya radang maka komponen susu berkurang termasuk pada lemak susu, sehingga dapat dikatakan bahwa semakin tinggi tingkat mastitis maka semakin rendah kadar lemak susu.

Protein. Pengujian kadar protein menggunakan Lactoscan menghasilkan rerata diatas $\mathrm{SNI}$ susu segar yaitu minimal $2.8 \%$. Hasil uji kadar protein disajikan pada Tabel 5.

Tabel 5 menunjukkan bahwa pada P0 dan P3 terjadi penurunan kadar protein 
Tabel 4. Rerata hasil uji kadar lemak susu (the mean of milk fat level)

\begin{tabular}{lcc}
\hline \hline & Sebelum perlakuan (\%) (before treatment $(\%))$ & Sesudah perlakuan (\%) (after treatment (\%)) \\
\hline P0 & 4.6725 & 3.665 \\
P1 & 4.6025 & 4.3325 \\
P2 & 4.5475 & 4.735 \\
P3 & 4.205 & 4.025 \\
\hline
\end{tabular}

P0: suhu $19-22^{\circ} \mathrm{C}$, tanpa dipping (temperature $19-22^{\circ} \mathrm{C}$, without teat dipping).

$\mathrm{P} 1$ : suhu $19-22^{\circ} \mathrm{C}$ dengan dipping setelah pemerahan (temperature $19-22^{\circ} \mathrm{C}$ with teat dipping after milking).

$\mathrm{P} 2$ : suhu $37^{\circ} \mathrm{C}$ dengan dipping sesudah pemerahan (temperature $37^{\circ} \mathrm{C}$ with teat dipping after milking).

P3: suhu $37^{\circ} \mathrm{C}$ dengan dipping sebelum dan sesudah pemerahan) (temperature $37^{\circ} \mathrm{C}$ with teat dipping before and after milking).

Tabel 5. Rerata hasil uji kadar protein susu (the mean of milk protein test)

\begin{tabular}{lcc}
\hline \hline & Sebelum perlakuan (\%) (before treatment (\%)) & Sesudah perlakuan (\%) (after treatment (\%)) \\
\hline P0 & 3.0575 & 3.0525 \\
P1 & 3.03 & 3.04 \\
P2 & 3.09 & 3.135 \\
P3 & 2.995 & 2.9625 \\
\hline
\end{tabular}

P0: suhu $19-22^{\circ} \mathrm{C}$, tanpa dipping (temperature $19-22^{\circ} \mathrm{C}$, without teat dipping).

$\mathrm{P} 1$ : suhu $19-22^{\circ} \mathrm{C}$ dengan dipping setelah pemerahan (temperature $19-22^{\circ} \mathrm{C}$ with teat dipping after milking).

$\mathrm{P} 2$ : suhu $37^{\circ} \mathrm{C}$ dengan dipping sesudah pemerahan (temperature $37^{\circ} \mathrm{C}$ with teat dipping after milking).

P3: suhu $37^{\circ} \mathrm{C}$ dengan dipping sebelum dan sesudah pemerahan) (temperature $37^{\circ} \mathrm{C}$ with teat dipping before and after milking).

sebesar 0,005\% dan 0,035\%, tetapi P1 dan P2 terjadi kenaikan kadar protein, sebesar 0,01 dan 0,045\%. Namun baik kenaikan dan penurunan kadar protein tidak signifikan. Hasil pada akhir perlakuan tidak dipengaruhi oleh suhu air pencucian ambing. Perubahan kadar protein dsebabkan adanya pemberian ransum pakan yang tidak stabil. Sagitarini et al. (2013) menyatakan bahwa kadar protein susu dipengaruhi oleh konsentrat, karena nutrisi dalam hijauan belum mencukupi kebutuhan nutrisi tubuh ternak. Selain itu kadar protein dipengaruhi oleh bulan laktasi, semakin bertambah bulan laktasi, semakin tinggi kadar protein.

Berat jenis. Berat jenis susu adalah angka perbandingan antara berat dan volume susu (Mardalena, 2008), Berdasarkan uji kualitas susu dengan Lactoscan didapatkan berat jenis susu yang tersaji pada Tabel 6.

Tabel 6 menunjukkan pada P0, P1, P2 terjadi kenaikan berat jenis sebesar 0,45, 0,41 dan 0,24 sedangkan P3 berat jenis turun sebesar 0,31 . Namun dari semua perlakuan, berat jenis susu di lapang masih memenuhi standar mutu susu segar yaitu 1,027. Hasil penelitian dengan suhu air pencucian ambing dengan suhu $37^{\circ} \mathrm{C}$ tidak berpengaruh terhadap berat jenis susu. Mardalena (2008) menyebutkan bahwa berat jenis susu dipengaruhi oleh kadar lemak dan bahan kering, berat jenis susu berbanding terbalik dengan kadar lemak susu, sehingga semakin tinggi kadar lemak susu semakin rendah berat jenis susu. Berdasarkan peneltian yang dilakukan Utami et al. (2014) menyebutkan bahwa konsentrat mempengaruhi berat jenis susu, semakin banyak konsentrat yang diberikan maka berat jenis susu semakin meningkat, karena konsentrat merupakan bahan pakan yang memiliki kandungan nutrisi yang lengkap sehingga dapat mempengaruhi besarnya kandungan bahan padat dalam susu.

Laktosa. Laktosa terdiri dari dua macam gula sederhana yaitu glukosa dan galaktosa. Adanya laktosa pada susu menyebabkan susu mempunyai rasa manis. Hasil pengujian kadar laktosa menggunakan Lactoscan tersaji pada Tabel 7.

Tabel 7 menunjukkan terdapat kenaikan kadar laktosa pada P0, P1 dan P2 berturut-turut sebesar $0.0072 \%, \quad 0,0325 \%$ dan $0,0525 \%$, sedangkan pada $\mathrm{P} 3$ terjadi penurunan kadar laktosa sebesar 0,0475\%. Hasil penelitian menunjukkan bahwa tidak ada pengaruh suhu air pencucian ambing terhadap kadar laktosa susu. Hal ini disebabkan bahwa kandungan laktosa dipengaruhi oleh pakan yang diberikan pada sapi perah. Diperkuat dengan penelitian Yusuf (2010) mengenai pemberian daun katu pada sapi menyebabkan meningkatnya mikroba rumen yang memproduksi VFA yang terdiri dari asam asetat, propionate dan asam 
Tabel 6. Rerata hasil uji berat jenis susu (the mean of milk density)

\begin{tabular}{lcc}
\hline \hline & Sebelum perlakuan (before treatment) & Sesudah perlakuan (after treatment) \\
\hline P0 & 27.6475 & 28.105 \\
P1 & 27.4425 & 27.86 \\
P2 & 28.1775 & 28.425 \\
P3 & 27.4225 & 27.1125 \\
\hline
\end{tabular}

P0: suhu $19-22^{\circ} \mathrm{C}$, tanpa dipping (temperature $19-22^{\circ} \mathrm{C}$, without teat dipping).

$\mathrm{P} 1$ : suhu $19-22^{\circ} \mathrm{C}$ dengan dipping setelah pemerahan (temperature $19-22^{\circ} \mathrm{C}$ with teat dipping after milking).

P2: suhu $37^{\circ} \mathrm{C}$ dengan dipping sesudah pemerahan (temperature $37^{\circ} \mathrm{C}$ with teat dipping after milking).

P3: suhu $37^{\circ} \mathrm{C}$ dengan dipping sebelum dan sesudah pemerahan) (temperature $37^{\circ} \mathrm{C}$ with teat dipping before and after milking).

Tabel 7. Rerata hasil uji kadar laktosa susu (the mean of milk lactose level test)

\begin{tabular}{ccc}
\hline \hline & Sebelum perlakuan (\%) (before treatment (\%)) & Sesudah perlakuan (\%) (after treatment (\%)) \\
\hline P0 & 4.32 & 4.3275 \\
P1 & 4.2725 & 4.305 \\
P2 & 4.38 & 4.4325 \\
P3 & 4.2475 & 4.2 \\
\hline
\end{tabular}

P0: suhu $19-22^{\circ} \mathrm{C}$, tanpa dipping (temperature $19-22^{\circ} \mathrm{C}$, without teat dipping).

$\mathrm{P} 1$ : suhu $19-22^{\circ} \mathrm{C}$ dengan dipping setelah pemerahan (temperature $19-22^{\circ} \mathrm{C}$ with teat dipping after milking).

P2: suhu $37^{\circ} \mathrm{C}$ dengan dipping sesudah pemerahan (temperature $37^{\circ} \mathrm{C}$ with teat dipping after milking).

P3: suhu $37^{\circ} \mathrm{C}$ dengan dipping sebelum dan sesudah pemerahan) (temperature $37^{\circ} \mathrm{C}$ with teat dipping before and after milking).

butirat, Asam propionat yang selanjutnya setelah proses gluko-neogenesis di hati akan terbentuk glukosa yang akan dibawah darah menuju ambing, dan glukosa merupakan precursor laktosa susu, semakin tinggi VFA maka laktosa susu yang dihasilkan meningkat. Adriani dan Mushawwir (2010) menyatakan bahwa penambahan suplementasi makro mineral $50 \%$ di atas yang direkomendasikan oleh NRC (2001), nyata meningkatkan kandungan laktosa susu, karena $\mathrm{Ca}, \mathrm{P}$ dan $\mathrm{Mg}$ sangat penting dalam metabolisme rumen sehingga meningkatkan mikroba rumen yang berkaitan erat dengan kerja enzim sellusa, sehingga peningkatan kadar laktosa disebabkan adanya peningkatan jumlah mikroba rumen.

Solid. Berdasarkan uji soliditas menggunakan Lactoscan terhadap susu sapi diperolah hasil yang tersaji pada Tabel 8 .
Tabel 8 menunjukkan bahwa pada semua perlakuan solid menurun setelah diberi perlakuan, P0, P1, P2, dan P3 berturut-turut menurun sebesar $0,0525 \%$, $0,0025 \%, 0,0075 \%$ dan $0,03 \%$. Namun baik sebelum dan susudah dilakukan perlakuan, solid tergolong tinggi diatas 0,7 . Solid tidak diakibatkan karena adanya perlakukan pencucian ambing dengan suhu yang berbeda (air suhu ruang dan suhu $37^{\circ} \mathrm{C}$ ), namun dipengaruhi pakan. Apabila dihubungkan dengan Tabel 3, menunjukkan bahwa solid tergantung pada kadar lemak. Mardalena (2008) menyebutkan bahwa apa bila kadar lemak tinggi maka persentase solid juga besar, namun pada penlitian ini kadar solid menurun. Kandungan solid yang menurun menunjukkan bahwa kemampuan ternak dalam memproduksi bahan-bahan penyusun susu adalah mengalami

Tabel 8. Rerata hasil uji soliditas (the mean of solidity test)

\begin{tabular}{lcc}
\hline \hline & Sebelum perlakuan (\%) (before treatment $(\%))$ & Sesudah perlakuan (\%) (after treatment (\%)) \\
\hline P0 & 0.8225 & 0.77 \\
P1 & 0.7775 & 0.775 \\
P2 & 0.79 & 0.7825 \\
P3 & 0.785 & 0.755 \\
\hline
\end{tabular}

P0: suhu $19-22^{\circ} \mathrm{C}$, tanpa dipping (temperature $19-22^{\circ} \mathrm{C}$, without teat dipping).

$\mathrm{P} 1$ : suhu $19-22^{\circ} \mathrm{C}$ dengan dipping setelah pemerahan (temperature $19-22^{\circ} \mathrm{C}$ with teat dipping after milking).

$\mathrm{P} 2$ : suhu $37^{\circ} \mathrm{C}$ dengan dipping sesudah pemerahan (temperature $37^{\circ} \mathrm{C}$ with teat dipping after milking).

$\mathrm{P} 3$ : suhu $37^{\circ} \mathrm{C}$ dengan dipping sebelum dan sesudah pemerahan) (temperature $37^{\circ} \mathrm{C}$ with teat dipping before and after milking). 
Tabel 9. Rerata hasil uji solid non fat (the mean of solid non fat test)

\begin{tabular}{lcc}
\hline \hline & Sebelum perlakuan (\%) (before treatment (\%)) & Sesudah perlakuan (\%) (after treatment (\%)) \\
\hline P0 & 8.19 & 8.185 \\
P1 & 8.1 & 8.155 \\
P2 & 8.295 & 8.4025 \\
P3 & 8.045 & 7.96 \\
\hline
\end{tabular}

P0: suhu $19-22^{\circ} \mathrm{C}$, tanpa dipping (temperature $19-22^{\circ} \mathrm{C}$, without teat dipping).

$\mathrm{P} 1$ : suhu $19-22^{\circ} \mathrm{C}$ dengan dipping setelah pemerahan (temperature $19-22^{\circ} \mathrm{C}$ with teat dipping after milking).

$\mathrm{P} 2$ : suhu $37^{\circ} \mathrm{C}$ dengan dipping sesudah pemerahan (temperature $37^{\circ} \mathrm{C}$ with teat dipping after milking).

P3: suhu $37^{\circ} \mathrm{C}$ dengan dipping sebelum dan sesudah pemerahan) (temperature $37^{\circ} \mathrm{C}$ with teat dipping before and after milking).

penurunan, dan sehingga dalam setiap liter produksi susu akan dihasilkan jumlah zat-zat nutrisi susu yang lebih sedkit, hal ini diperjelas dengan terjadinya penurunan yang nyata terhadap kadar lemak dan casein susu (Aryogi et al., 2001).

Solid non fat. Solid non fat (SNF) terdiri laktosa, protein, mineral dan vitamin. Berdasarkan hasil uji susu menggunakan Lactoscan diperoleh data yang tersaji pada Tabel 9.

Tabel 9 menunjukkan bahwa pada P0 dan P3 terjadi penurunan SNF sebesar 0,005 dan $0,085 \%$ sedangkan $\mathrm{P} 1$ dan $\mathrm{P} 2$ terjadi kenaikan SNF sebesar $0,055 \%$ dan $0,1075 \%$. Kadar SNF tertinggi diperoleh dari perlakuan 2 dan terendah pada perlakuan 3 namun masih masuk kategori standar mutu susu segar yaitu minimal 7,8\%. Perubahan SNF tersebut tidak dipengaruhi oleh perlakuan, namun SNF dipengaruhi oleh berat jenis susu, semakin tinggi berat jenis susu maka SNF juga semakin tinggi. Telah disebutkan bahwa berat jenis susu dipengaruhi oleh pemberian konsentrat. Selain itu SNF dapat dipengaruhi teknologi pengolahan pakan, Aryogi et al. (2001) menyebutkan bahwa dengan penerapan teknologi defaunasi ransum dapat meningkatkan BJ susu dari 1,026 menjadi 1,027 karena ternak mampu memproduksi bahan-bahan penyusun susu lebih banyak yaitu ditunjukkan dengan tingginya kadar SNF.

\section{Pengaruh suhu air pencucian ambing terhadap jumlah produksi susu}

Berdasarkan penghitungan jumlah produksi yang dilakukan pada pagi dan sore hari diperoleh rerata seperti yang disajikan pada Tabel 10 dan 11.

Tabel 10 menunjukkan bahwa pada P0 tidak mengalami perubahan pada jumlah produksi susu, sedangkan pada $\mathrm{P} 1$ terdapat peningkatan jumlah produksi susu yang tidak signifikan sebesar 4\%. Pada P2 dan P3 terdapat peningkatan secara sangat signifikan yaitu sebesar $8,9 \%$ dan $12 \%$. Sedangkan pada Tabel 11 menunjukkan bahwa setiap perlakuan mengalami peningkatan, $\mathrm{P} 0$ meningkat $0,8 \%, \quad \mathrm{P} 1$ meningkat $0,4 \%$, P2 meningkat $12,6 \%$ dan P3 meningkat sebesar 22,6\%. Dari hasil penghitungan terdapat peningkatan yang sangat signifikan pada P2 dan P3 yaitu dengan melakukan pencucian ambing dengan suhu $37^{\circ} \mathrm{C}$, karena secara teori dengan menggunakan air bersuhu $37^{\circ} \mathrm{C}$ dapat merangsang keluarnya susu dari kelenjar susu secara cepat (Suheri, 2010), selain itu dengan suhu tersebut membuat sapi merasa nyaman, hal ini terlihat pada tingkah laku ternak yang tenang saat ambing dicuci dengan air bersuhu $37^{\circ} \mathrm{C}$ sehingga

Tabel 10. Hasil produksi susu pagi

(the result of milk production in the morning)

\begin{tabular}{lcc}
\hline \hline & $\begin{array}{c}\text { Sebelum perlakuan (liter) } \\
\text { (before treatment (liter)) }\end{array}$ & $\begin{array}{c}\text { Sesudah perlakuan (liter) } \\
\text { (after treatment (liter)) }\end{array}$ \\
\hline P0 & 8.2 & 8.2 \\
P1 & 7.5 & 7.8 \\
P2 & 7.8 & 8.5 \\
P3 & 6.6 & 7.4 \\
P0: suhu $19-22^{\circ} \mathrm{C}$, tanpa dipping (temperature $19-22^{\circ} \mathrm{C}$, without teat dipping). \\
P1: suhu $19-22^{\circ} \mathrm{C}$ dengan dipping setelah pemerahan (temperature $19-22^{\circ} \mathrm{C}$ with teat dipping after milking). \\
P2: suhu $37^{\circ} \mathrm{C}$ dengan dipping sesudah pemerahan (temperature $37^{\circ} \mathrm{C}$ with teat dipping after milking). \\
P3: suhu $37^{\circ} \mathrm{C}$ dengan dipping sebelum dan sesudah pemerahan) (temperature $37^{\circ} \mathrm{C}$ with teat dipping before and after \\
milking).
\end{tabular}


Tabel 11. Hasil produksi susu sore

(the result of milk production in the afternoon)

\begin{tabular}{ccc}
\hline \hline & $\begin{array}{c}\text { Sebelum perlakuan (liter) } \\
\text { (before treatment (liter)) }\end{array}$ & $\begin{array}{c}\text { Sesudah perlakuan (liter) } \\
\text { (after treatment (liter)) }\end{array}$ \\
\hline P0 & 6.2 & 6.25 \\
P1 & 5.75 & 5.775 \\
P2 & 5.325 & 6 \\
P3 & 4.85 & 5.95 \\
\hline
\end{tabular}

P0: suhu $19-22^{\circ} \mathrm{C}$, tanpa dipping (temperature $19-22^{\circ} \mathrm{C}$, without teat dipping).

$\mathrm{P} 1$ : suhu $19-22^{\circ} \mathrm{C}$ dengan dipping setelah pemerahan (temperature $19-22^{\circ} \mathrm{C}$ with teat dipping after milking).

$\mathrm{P} 2$ : suhu $37^{\circ} \mathrm{C}$ dengan dipping sesudah pemerahan (temperature $37^{\circ} \mathrm{C}$ with teat dipping after milking).

$\mathrm{P} 3$ : suhu $37^{\circ} \mathrm{C}$ dengan dipping sebelum dan sesudah pemerahan) (temperature $37^{\circ} \mathrm{C}$ with teat dipping before and after milking).

susu yang dikeluarkan lebih maksimal. Pujiati dan Indrianto (2009) menyatakan bahwa melakukan pencucian ambing dengan air hangat lebih berfungsi untuk merangsang keluarnya hormone oksitosin dalam produksi susu.

Faktor lain yang mempengaruhi produksi susu yaitu kemampuan kelenjar ambing sebagai pabrik biologis untuk menghasilkan susu, untuk mewujudkan kemampuan ini maka keberadaan jumlah dan potensi sel-sel epitel kelenjar ambing sangat menentukan, sehingga jumlah sel epitel di dalam kelenjar ambing yang semakin banyak secara normal dapat meningkatkan produktifitas jumlah susu (Ramelan, 2001). Keadaan sel ambing juga dapat dipengaruhi adanya mastitis, karena adanya kerusakan pada sel ambing sehingga dapat menurunkan produksi susu karena adanya peningkatan jumlah sel somatik susu sehingga pembuatan komponen susu lebih sedikit (Surjowardojo, 2012).

\section{Kesimpulan}

Teat dipping mampu memperlama waktu reduktase susu dan menurunkan angka sel somatik. Suhu air pencucian ambing $37^{\circ} \mathrm{C}$ tidak mempengaruhi komponen susu, namun dapat mempengaruhi jumlah produksi susu.

\section{Ucapan Terima Kasih}

Penulis mengucapkan terima kasih kepada Jeky M. Sui, S.Si yang telah membantu dalam analisis data.

\section{Daftar Pustaka}

Ace, I. dan Wahyuningsih. 2010. Hubungan variasi pakan terhadap mutu susu. Jurnal Penyuluhan Pertanian 5: 67-77.
Adriani. 2010. Penggunaan sel somatic count (SCC), jumlah bakteri dan californa mastitis test (CMT) untuk deteksi mastitis pada kambing. Jurnal IImiah IImu-ilmu Peternakan XIII: 229-234.

Adriani, L. dan A. Mushawwir. 2010. Kadar Glukosa Darah, Laktosa dan Produksi Susu Sapi Perah pada Berbagai Tingkat Suplementasi Mineral Makro. Fakultas Peternakan, Universitas Padjajaran, Bandung.

Affandy A., F. Andrini, dan S. Lesmana. 2009. Penentuan hambat minimal dan konsentrasi bunuh minimal larutan povidon iodium $10 \%$ terhadap Staphylococcus aureus Resisten Metisilin (MRSA) dan Staphylococcus aureus Sensitif Metisilin. Jurnal IImu Kedokteran 3: 14-19.

Aryogi, Yusran, Umiyasih, Rasyid, Affandhy, dan Arianto. 2001. Pengaruh Teknologi Defaunasi Pada Ransum Terhadap Produktifitas Ternak Sapi Perah Rakyat. Instalasi Penelitian dan Pengkajian Teknologi Pertanian Grati Pasuruan dan Wonocolo, Surabaya.

Gilson, W. D. 2015. Question dan answer about pre-dipping http://www.ads.uga.edu/documents/qu estionsandanswersaboutpredippping.pdf. Diakses 11 Januari 2016.

Kentjonowaty, I., P. Trisunuwati, T. Susilawaty, dan P. Surjowardojo. 2014. Evaluasi Profil Hormon Oxytocin, Kualitas dan Kuantitas Produksi Susu Sapi Perah pada Lama Mammae Hand Massage dari Berbagai Metode Pemerahan. Fakultas Peternakan, Universitas Brawijaya, Malang. 
Kurniawan, I., Sarwiyono, dan P. Surjowardojo, 2013. Pengaruh teat dipping menggunakan dekok daun kersen (Muntingia calibura L.) terhadap tingkat kejadian mastitis. Jurnal IImu-ilmu Peternakan 23: 27-31.

Mardalena. 2008. Pengaruh waktu pemerahan dan tingkat laktasi terhadap kualitas susu sapi perah Peranakan Fries Holstein. Jurnal IImuilmu Peternakan 11: 107-111.

Musnandar, E. 2011. Efisiensi energi pada sapi perah Holstein yang diberi berbagai imbangan rumput dan konsentrat. Jurnal Penelitian Universitas Jambi Seri Sains 13: 5358.

Mutamimah, L., Utami, dan Sadewo. 2013. Kajian kadar lemak dan bahan kering tanpa lemak susu kambing Sapera di Cilacap dan Bogor. Jurnal IImiah Peternakan. 1: 874-880.

Nickerson, S. 2013. Choosing the best teat dip for mastitis control and milk quality. Hill Farm Reseacrh Station. Louisiana State Univesity Agricultural Center. Homer, Loisiana.

NRC. 2001. Nutrient requirements of dairy cattle. $7^{\text {th }}$ Revised edn, Subcommittee on Dairy Cattle Nutrition, Committee on Animal Nutrition, Board on Agriculture and Natural Resources, National Research Council, National Academy Press, Washington, D.C.

Racjevic, M., K. Potocnick and J. Levstek. 2003. Correlations between somatic cell count and milk composition with regrad to the season. Agriculturae Conspectus Scientificus 68: 221-226.

Pujiati, R. dan T. Indrianto. 2009. Perbedaan kandungan bakteriologi susu segar ditinjau dari pemakaian desinfektan dan tanpa desinfektan pada ambing sapi sebelum pemerahan. Jurnal IKESMA 5: 31-45.

Ramelan. 2001. Efisisensi produksi air susu pada sapi perah dara dan laktasi akibat penyuntikan PMSG. Proram Studi Magister IImu Ternak, Program Pascasarjana, Fakultas Peternakan, Univesitas Diponegoro, Semarang.

Ruegg, P. and J. Pantoja. 2013. Understanding and using soatic cell count to improve milk quality. University of Wisconsin Madison and Federal, University of Sao Paulo, Botocatu Brazil. Irish Journal of
Agricultural and Food Research 52: 101-117.

Sagitarini, D., S. Usmiati, dan T. Astuti. 2013. Kadar protein dan nilai viskositas susu kambing Sapera di Cilacap dan Bogor. Jurnal Ilmiah Peternakan 1: 1057 1063.

Sharma, N., N. Singh and Bhadwal. 2011. Reletionship of somatic cell count and mastitis. Asian-Aust. J. Anim. Sci. Vol. 24: 429-438.

Sugiri, Y. dan A. Anri. 2014. Prevelensi patogen penyebab masttis subklinis (Staphylococcus aureus dan Streptococcus agalactiae) dan patogen penyebab mastitis subklinis lain pada peternak skala kecil dan menengah di beberapa sentra peternakan sapi perah di Pulau Jawa. Balai Pengujian dan Penyidikan Penyakit Hewan dan Kesmavet, Lembang, Bandung.

Suheri, G. 2010. Teknik pemerahan dan penanganan susu sapi perah. Lokakarya Fungsional Non Peneliti, Balai Penelitian Ternak Ciawi, Bogor.

Suriyasathaporn, W. and V. Chupia. 2011. Reduction in number of bacteria after pre-milking teat dipping in milking dairy cows. J. Nat. Sci. 10: 301-306.

Surjowardojo, P., Suyadi, L. Hakim, dan Aulani'am. 2008. Ekspresi produksi susu pada sapi perah. Jurnal Ternak Tropika 9: 1-11.

Surjowardojo, P. 2011. Tingkat kejadian mastitis dengan whiteside test dan produksi susu sapi perah Frisien Holstein. Jurnal Ternak Tropika 12: 4655.

Surjowardojo, P. 2012. Penampilan kandungan protein dan kadar lemak susu pada sapi perah mastitis Frisian Holstein. J. Exp. Life. 12: 42-48.

Utami, K., L. Radiati, dan P. Surjowardojo. 2014. Kajian kualitas susu sapi PFH (Studi kasus pada anggota KAN di Kecamatan Jabung Kabupaten Malang). Jurnal Ilmu-ilmu Ternak 24: 58-66.

Wibowo, M. 2005. Analisis Kelayakan Usaha Susu Sapi Murni pada Perusahaan Rahmawati Jaya. Jurusan Sosial Ekonomi Pertanian, Fakultas Sains dan Teknologi, Universitas Islam Negeri Syarif Hidayatullah, Jakarta. 
Widaningrum, S. Usmiati, dan Abubakar. 2006. Penerapan HACCP pada prosesmpemerahan susu sapi di tingkat peternakan (Kasus koperasi usu Sarwa Mukti Kecamatan Cisarua Kabupaten Bandung 2005). Prosiding Seminar Nasional Teknologi Peternakan dan Veteriner, Bogor 5-6 September 2006.
Yusuf, R. 2010. Kandungan protein susu sapi perah friesian holstein akibat pemberian pakan yang mengandung tepung katu (Sauropus androgynus (L) (Merr) yang berbeda. Jurnal Teknologi Pertanian 6: 1-6. 